\title{
Velhice e analfabetismo, uma relação paradoxal: a exclusão educacional em contextos rurais da região Nordeste
}

Recebido:

02/12/09

Aprovado 23/12/10

1. Professor Adjunto do Departamento de Filosofia e Ciências Humanas (DFCH) da Universidade Estadual de Santa Cruz (UESC), campus de Ilhéus - BA.

E-mail: mperes@usp.br

Marcos Augusto de Castro Peres ${ }^{1}$

Resumo: Este artigo procura analisar a relação entre velhice e analfabetismo na região Nordeste do Brasil, especialmente em duas áreas: o semiárido do Rio Grande do Norte e a zona cacaueira do Sul da Bahia. De acordo com o Censo 2010 do IBGE, é na região Nordeste onde se verificam os maiores índices de analfabetismo do país. O problema do analfabetismo atinge principalmente as populações mais idosas, de cor negra e parda, do sexo feminino, e os residentes nas áreas rurais. A relação existente entre latifúndio e analfabetismo explica, em parte, a maior incidência desse problema na região Nordeste, onde há maior concentração de renda e também da propriedade rural. A inexistência, no Brasil, de políticas educacionais direcionadas à velhice e ao analfabetismo pode ser observada na ausência dessas questões nas leis específicas, como a LDB (da educação) e o Estatuto do Idoso (da velhice). Por fim, a compreensão da problemática sob a ótica da Sociologia representa contribuição teórica relevante para os estudos educacionais. Palavras-chave: Velhice, Analfabetismo, EJA, Política Educacional, Nordeste.

Introdução

S oa até estranho pensar na relação entre velhice e educação, numa sociedade que tem a infância e a juventude como fases tradicionalmente destinadas à vida escolar. Philippe Ariès (1981) mostrou que o surgimento da sociedade moderna industrial e a universalização da educação escolar seriam os principais determinantes da delimitação da infância como fase diferenciada da vida adulta, posto que, até a Idade Média, a criança era vista como um "adulto em miniatura". Sabemos que a educação pedagógica adotada nessa sociedade tinha a finalidade primeira de formar e disciplinar o futuro trabalhador da indústria. E, principalmente por isso, a educação escolar adotou os métodos pedagógicos, destinados à formação nas primeiras fases da vida.

Por outro lado, as pessoas de mais idade foram excluídas desse projeto 
educacional, pois não interessavam mais ao processo produtivo. Isso porque tais pessoas não precisariam ser formadas para uma futura vida profissional, pois ou já eram trabalhadores prestes a se aposentar ou já estavam aposentados. A lógica era a seguinte: para quê se investir na educação dos que já passaram pela vida produtiva ou que estavam em vias de sair dela? Isso seria um desperdício do ponto de vista do capitalismo, pois esses indivíduos não poderiam mais contribuir para a produção da riqueza (RAMOS, 2001).

Essa situação explica, em grande medida, a ausência de um projeto educacional destinado especificamente aos mais velhos, quando consideramos o modelo capitalista de educação. E isso se verifica na totalidade dos países capitalistas, que construíram, ao longo da história, uma estrutura de ensino formal para educar prioritariamente crianças e jovens. A chamada "educação de adultos" ou de "jovens e adultos", surgiria posteriormente na sociedade industrializada, pela necessidade de preparar minimamente a classe operária, derivada do "campesinato bruto e ignorante" (PINTO, 2005).

No Brasil, as principais leis da educação, como a LDB (Lei 9.394/96), também citam, no máximo, a educação de jovens e adultos (EJA) como única alternativa educacional destinada à população "fora da idade escolar". Contudo, essas leis não tratam da diversidade existente entre os indivíduos que compõem a categoria de adultos. Por exemplo, há muita diferença entre um adulto de 25 ou 30 anos e um "adulto" (ou idoso?) de 50 ou 60 anos. E isso em nenhum momento é levado em consideração na LDB, lei que, aliás, nem sequer cita a velhice, ignorando-a totalmente. Poder-se-ia supor que os idosos integrariam, nesse caso, a categoria de adultos. Contudo, não diferenciar a velhice da vida adulta, como fase que demanda atenção especial, bem como metodologias próprias de ensino/aprendizagem, seria assumir uma perspectiva no mínimo reducionista, análoga à consideração da infância como uma "vida adulta em miniatura", que vigorou no período medieval, conforme mostra Ariès (1981).

Tomemos o analfabetismo como um dos exemplos mais graves de exclusão educacional e social. Se considerarmos o acesso à educação formal como a possibilidade de ter contato com o conhecimento científico, a literatura, a filosofia, a arte, enfim, com a linguagem escrita como forma de expressão e comunicação, então constatamos que não saber ler e escrever significa não dispor dos recursos de interação com o "mundo civilizado" da sociedade ocidental capitalista.

Sabemos que, segundo o IBGE (Censo 2000), a maioria da população não-alfabetizada no Brasil é composta por pessoas de idade mais avançada, ou seja, idosos e adultos mais velhos, especialmente as mulheres, os negros e afrodescendentes, os indígenas e os residentes nas áreas rurais e na região Nordeste. Sabemos que existem escolas destinadas às crianças, aos jovens e, até 
mesmo, aos adultos trabalhadores (da indústria), como é o caso da EJA. Mas, por outro lado, não há escolas destinadas aos idosos, e que atendam especificamente às suas necessidades e peculiaridades enquanto sujeitos sociais (PERES, 2009).

Conforme mostra uma pesquisa da Fundação Perseu Abramo, O perfil sóciodemográfico dos idosos brasileiros, concluída em 2007, metade da população idosa brasileira urbana é atingida pelo analfabetismo funcional. De acordo com os dados, entre a população idosa, o analfabetismo funcional totaliza 49\% (13\% entre os não idosos): $23 \%$ declaram não saber ler e escrever ( $2 \%$ dos não idosos), $4 \%$ afirmam só saber ler e escrever o próprio nome ( $1 \%$ dos não idosos) e $22 \%$ consideram a leitura e a escrita atividades penosas ( $8 \%$ dos não idosos), seja por deficiência de aprendizado (14\%), por problemas de saúde (7\%) ou por ambos os motivos (2\%). Além disso, observa-se que, entre os idosos, $89 \%$ não passaram da 8 a série do ensino fundamental ( $18 \%$ não tiveram nenhuma educação formal) e apenas $4 \%$ chegaram ao 30 grau de escolaridade (completo ou incompleto). Entre os não idosos, $44 \%$ não passaram do fundamental ( $2 \%$ não frequentaram escolas) e $15 \%$ chegaram ao ensino superior ${ }^{2}$.

De acordo com o Instituto Nacional de Pesquisas Educacionais (INEP), no relatório Mapa do analfabetismo no Brasil, publicado em 2003, também vemos que o maior contingente de analfabetos $(48,7 \%)$ encontrava-se nos grupos etários mais idosos, com pessoas de idade igual ou superior a 50 anos. Comparativamente às outras faixas etárias, nota-se que a dos idosos é a que mais necessitaria de ações do governo na esfera da educação, uma vez que é a mais prejudicada pelo que podemos chamar de "exclusão educacional". Contudo, de forma paradoxal, os idosos são exatamente o único grupo etário que não é assistido pelo Poder Público nas atuais políticas educacionais.

É bom lembrar que a Constituição de 1988 garante o alcance indiscriminado da oferta obrigatória e gratuita do ensino público fundamental, estendido a toda população, independente da idade (art. 208, I). Na condição de direito público subjetivo, a educação possui acesso gratuito aos níveis de ensino, conforme o art. 208, § 1ㅇda CF/88. Contudo, o não oferecimento da educação por parte do Poder Público implica na responsabilização da autoridade competente (art. 208, $\S 2$ o da CF/88). Assim, a gratuidade do ensino público nos estabelecimentos oficiais (art. 206, IV da CF/88), é um princípio educacional com força constitucional, o que revela a forte dimensão democrática e social da Constituição de 1988.

Dessa forma, ao não contemplar os idosos como destinatários das políticas educacionais, o Estado brasileiro descumpre a própria Constituição, dessa vez não por ação, mas por omissão. É necessário destacar, contudo, que tal omissão é coerente à própria lógica de exclusão verificada na sociedade capitalista
2. Fundação Perseu Abramo; Pesquisa: Idosos no Brasil: vivências, desafios $e$ expectativas na 3 a idade, cap. 1: "Perfil sócio-demográfico dos idosos brasileiros"; 07/05/2007. 
(e não só no Brasil) e à forma pela qual os sistemas educacionais foram construídos, especialmente no capitalismo industrial. Por isso, acredito ser necessário entrar agora, mesmo que brevemente, no terreno da história e da filosofia da educação.

\section{O capitalismo industrial e a funcionalidade da educação}

Falar de escola e de educação implica tratar fundamentalmente do conceito de formação. Em termos gerais, é a escola que "forma" os indivíduos para que estes venham a ocupar um determinado papel na sociedade. De uma forma geral, nas sociedades capitalistas da atualidade, cada uma das diversas "fases" ou períodos da trajetória escolar está associada a uma fase específica da vida humana. Desconsiderando casos excepcionais, pode-se dizer que a educação infantil (pré-escola) marca a primeira infância, o ensino fundamental marca a segunda infância e a pré-adolescência, enquanto que o ensino médio está associado à adolescência. Passar no vestibular e ingressar na universidade, por sua vez, representa um ritual que marca o início da vida adulta.

Esses "rituais de passagem" que caracterizam a trajetória da educação escolar em nossa sociedade simbolizam a evolução dos diferentes estágios de maturidade em que a vida humana é periodizada. Assim, passar da infância para a pré-adolescência, da pré-adolescência para a adolescência e da adolescência para a vida adulta implica concluir os diversos ciclos escolares, da pré-escola ao ensino superior. Em outras palavras, significa "se formar", uma vez que a formatura representa o "ritual" que marca a conclusão de uma determinada fase da trajetória educacional (ARIÈS, 1981).

Ariès (1981) mostra que a infância como fase separada da vida adulta não existia na Idade Média, passando a ser social e historicamente construída com o advento da modernidade e da sociedade industrial. Da mesma forma, a escola, tal como a conhecemos hoje, surgiria praticamente no mesmo contexto histórico em que se deu a delimitação da infância como fase diferenciada da vida humana. Era comum o trabalho infantil nos primórdios da Revolução Industrial. Com a Revolução Francesa, a Declaração dos Direitos do Homem e do Cidadão e, posteriormente, com a emergência do movimento socialista, o trabalho da criança passou a ser gradualmente combatido e proibido, tornando-se ilegal. Contudo, a sua proibição se daria simultaneamente ao surgimento da escola como um lócus apropriado para a permanência da criança e para a sua socialização. Como se pode notar, a ideia de escola passa a estar diretamente associada à de infância. O próprio termo "pedagogia", que significa a teoria ou a ciência da educação e do ensino, tem sua origem voltada para a educação de crianças. 
Na etimologia da palavra, que tem origem grega, paidós quer dizer criança (PERES, 2005).

Mas se, por um lado, a noção de escola está simbolicamente associada à de infância e de adolescência, ou melhor, diz respeito àquele ou àquela que ainda não se iniciou na vida adulta, a noção de trabalho, por outro, tem relação direta com os níveis de maturidade. Na trajetória escolar, a conclusão do ensino médio marca o início da fase adulta, seja pelo ingresso na universidade ou diretamente no mercado de trabalho, sendo que essa última opção é mais comum nas classes populares, que possuem maior dificuldade de acesso à universidade. Vemos aí, portanto, um dos mais evidentes antagonismos presentes na interface entre trabalho e educação, criado pela moderna sociedade capitalista: é o "adulto" que trabalha e a "criança" que estuda. Tal antagonismo fundamenta-se na associação direta entre maturidade e vida profissional. Contudo, é no conceito de "formação" que podemos estabelecer um elo entre trabalho e educação. A formação escolar, considerando toda a sua trajetória "natural", visa formar o indivíduo para que este assuma um papel social. Dito de outra forma, para que ele adquira uma identidade social. E, na atual sociedade capitalista, tal identidade é construída fundamentalmente por meio do trabalho e da identidade profissional (DUBAR, 1995).

Na verdade, a própria trajetória educacional dada pelas fases escolares, que tem como "final da cadeia" o ingresso no ensino superior - onde o indivíduo faz, enfim, a opção por uma carreira profissional -, evidencia uma relação clara entre trabalho e educação, dada pela lógica da formação educacional/profissional. Seja no nível técnico do ensino médio, ou no ensino superior, a trajetória educacional dos indivíduos se encerra com a escolha de uma determinada profissão. Ao "completar" os estudos de nível superior ou técnico, o ex-aluno estará "apto ao trabalho". Assim, nas sociedades capitalistas, coloca-se o trabalho e a vida profissional como a referência chave da vida social. Em síntese, estuda-se, "forma-se", para trabalhar, para ter uma profissão e, com isso, assumir um papel específico na sociedade. Daí a conhecida "teoria do capital humano", surgida na década de 1960, nos EUA, fundada na "economia da educação", segundo a qual a educação é compreendida como produtora de capacidade de trabalho e potencializadora do fator trabalho (MORAES, 1999).

Essa visão economicista e funcionalista da educação como formadora de recursos humanos para o trabalho produtivo torna evidente o porquê de o sistema educacional ter sido estruturado tendo como "final da cadeia" a formação para o mercado de trabalho. A escola, na sociedade capitalista passa a ser vista como um "aparelho ideológico de Estado", reproduzindo a sua lógica instrumental, com o fim de atender aos interesses da classe economicamente dominante (ALTHUSSER, 1992). 
Seria, portanto, a necessidade de mão-de-obra qualificada, inerente ao rápido desenvolvimento da sociedade capitalista industrial, que determinaria a estrutura organizacional do atual sistema educacional, colocando a formação para o trabalho como objetivo central e configurando uma "produção em série" de mão-de-obra intelectualmente melhor preparada do que nas fases iniciais da industrialização, por meio da constituição de uma escola capitalista com currículos e conteúdos de um forte caráter tecnicista e ideológico (FRIGOTTO, 1984).

3. É de grande importância, nas Ciências Sociais, a ideia de estranhamento. O exercício de "tornar o familiar estranho e o estranho familiar" permite relativizar, questionar e desconstruir os padrões culturais cristalizados da realidade social, através da pesquisa antropológica ou sociológica (DAMATTA 1997).

\section{Educação, trabalho e velhice na sociedade capitalista}

Mas se a ideia de educação (pedagógica) está associada à imagem da criança e a de trabalho ou formação profissional (técnica e/ou universitária) vincula-se à imagem do adulto ou do jovem com certo grau de maturidade, onde entram, então, os idosos nesse processo? Qual o lugar da velhice na relação entre educação, trabalho e formação profissional?

$\mathrm{Na}$ verdade, causa até certo estranhamento pensar nessa relação ${ }^{3}$. Isso porque a sociedade capitalista estruturou um sistema educacional e produtivo coerente aos seus interesses, relegando os idosos ao esquecimento. A criança deve ser educada para que, quando adulto, venha a ser um trabalhador adequado às necessidades da sociedade. 0 jovem e o adulto devem ser formados e profissionalizados para assumirem uma função específica dentro da esfera produtiva, garantindo, assim, a eficiência do sistema econômico em constante desenvolvimento e mudança. E o velho? Onde entra? A verdade é que não há lugar para a velhice dentro da sociedade capitalista. Essa "realidade incômoda" de exclusão social que acompanha a velhice já foi observada e analisada por autores como Simone de Beauvoir (1990) e Ecléa Bosi (1994).

Na perspectiva do capital, o velho representa o trabalhador que já se tornou improdutivo e obsoleto e que deve dar lugar às novas gerações de trabalhadores, dotadas de conhecimentos atualizados e de uma maior disposição para o trabalho. Como dizia Karl Marx (1983), o capital não se preocupa com o tempo de duração da força de trabalho, uma vez que seu exército industrial de reserva tende a ser numericamente abundante. Assim, o velho deve ser expulso, retirado do mercado de trabalho. A aposentadoria, de certa forma, assume, simbolicamente, o significado de retirada ou saída da vida produtiva. Isso é bem claro pelas suas designações em outros idiomas, como no inglês (retired) e no francês (retrait). A velhice, então, é claramente excluída do projeto capitalista de educação, uma vez que a elite industrial nunca possuiu um projeto para os trabalhadores que envelheciam, a não ser criar estratégias para os excluir da esfera produtiva - tal como a garantia do direito à aposentadoria -, 
dando lugar aos jovens trabalhadores, recentemente "educados" ou "formados".

Quando nos questionamos o porquê da educação formal se restringir apenas às fases iniciais da vida humana, não há como negar o seu caráter funcional frente ao sistema produtivo. Apesar da resistência dos pedagogos em aceitar essa realidade, é inegável que o sistema educativo é não só pré-determinado como também subjugado pelo sistema produtivo na sociedade capitalista. $\mathrm{Na}$ verdade, a exclusão da velhice da esfera produtiva justifica a sua exclusão, também, do sistema educativo, centrado nas práticas pedagógicas de educação, voltadas exclusivamente ao jovem e à criança.

É comum, entre os pedagogos, defender que a educação tem o propósito de "preparar para o exercício da cidadania", de "formar cidadãos conscientes dos seus direitos e deveres". Contudo, sabe-se que a moderna sociedade industrial passou a demandar uma mão-de-obra altamente qualificada e, ao mesmo tempo, disciplinada para o processo de trabalho. Era necessário formar não só profissionais capacitados a desempenhar funções de elevada complexidade, mas também trabalhadores e cidadãos disciplinados, que respeitassem a ordem estabelecida e cumprissem seus papéis na sociedade. Ora, todos que conhecem a crítica do materialismo histórico à ideia de cidadania sabem que ela é vista, acima de tudo, como uma estratégia da burguesia para permitir uma participação ou ação política dentro dos limites estreitos da democracia capitalista e que, principalmente, não venha a comprometer o seu caráter estrutural de dominação. O Estado capitalista permite e até incentiva a prática da cidadania porque ela não representa uma ameaça real às suas estruturas de poder, uma vez que sua esfera de ação está dentro do sistema e, portanto, sob o controle deste (DIAS, 1999).

Assim, vemos que o discurso de "educação para a cidadania", proferido com orgulho por muitos teóricos da Pedagogia, é também coerente à lógica funcionalista da educação formal, subjugada à esfera produtiva na sociedade capitalista e aos seus projetos de dominação político-ideológica.

A educação e a dicotomia rural/urbano: analfabetismo, velhice e ruralidade

Se, por um lado, podemos questionar por que a nossa educação se restringe à infância, à adolescência e à fase adulta - excluindo, portanto, a velhice -, por outro, entretanto, também é possível perguntar sobre os motivos de o nosso sistema educacional estar focado prioritariamente na vida urbana. Como a atual educação escolar foi estruturada com a emergência da sociedade 
urbano-industrial capitalista, não é de se estranhar que o meio rural ficasse relegado ao esquecimento, na condição de mero "apêndice" da vida urbana. 0 resultado disso é a construção de uma educação centrada na vida da cidade e distante da vida no campo. E esse distanciamento se revela tanto nos currículos e conteúdos adotados (geralmente contextualizados à vida urbana e desconectados da dinâmica da vida rural), quanto pela precariedade das escolas disponíveis no campo.

Não sem motivo, é no meio rural que encontramos os mais baixos índices de escolaridade de toda a sociedade brasileira. Os dados do INEP, sistematizados no trabalho intitulado Panorama da Educação do Campo (2007), mostram que a escolaridade média da população de 15 anos ou mais, que vive no meio rural brasileiro, que é de 3,4 anos, corresponde à quase metade da estimada para a população urbana, que é de 7,0 anos. Se os índices de analfabetismo no Brasil são bastante elevados, no meio rural esses indicadores são ainda mais preocupantes. Segundo o IBGE (Censo 2000), 29,8\% da população adulta - de 15 anos ou mais -, que vive no meio rural é analfabeta, enquanto no meio urbano essa taxa é de 10,3\%. É importante ressaltar que a taxa de analfabetismo aqui considerada não inclui os analfabetos funcionais, ou seja, aquela população com menos de quatro séries do ensino fundamental. Outros dados revelam ainda que, no meio rural brasileiro, 6\% das crianças, de 7 a 14 anos, encontram-se fora dos bancos escolares; que apesar de 65,3\% dos jovens, de 15 a 18 anos, estarem matriculados, $85 \%$ deles apresentam defasagem de idade-série, o que indica que eles ainda permanecem no ensino fundamental; e que somente $2 \%$ dos jovens que moram no campo frequentam o ensino médio.

Esses são alguns dos indicadores que demonstram a histórica negação à população que vive no meio rural brasileiro do direito de acesso e de permanência na escola. Os que hoje integram a população idosa foram vítimas, no passado, dessa dificuldade. As altas taxas de analfabetismo observadas entre a população com 60 anos ou mais no Brasil, que é de 34,6\%, segundo o IBGE (Censo 2000), justificam-se, em grande parte, pela precariedade da educação no meio rural, uma vez que, segundo a PNAD (2007), a porcentagem de idosos analfabetos aumenta nos interiores dos estados e diminui nas capitais. Portanto, o que engrossa as estatísticas de analfabetismo na velhice é, acima de tudo, o problema histórico do acesso à educação verificado no meio rural. Contudo, é bom lembrar que esse não é um problema restrito à população idosa, mas sim um problema crônico do próprio sistema, pois novos analfabetos estão sendo gerados diariamente.

A educação do campo, bem como os programas de alfabetização de adultos (EJA), são formas de educação popular voltadas aos indivíduos que não puderam ter acesso à educação formal na "idade própria" (como diz a LDB), 
ou seja, na infância. Tal situação de déficit educacional entre adultos, observada particularmente nos países subdesenvolvidos, decorre, sobretudo, da ausência ou insuficiência de oferta educacional, principalmente nas regiões menos desenvolvidas do país. O trabalho rural, executado pelo "camponês" ou "homem do campo", está associado historicamente à exclusão da educação formal. O trabalho industrial, ao contrário, conecta-se aos chamados "conhecimentos superiores", à ciência e à técnica, inerentes à vida urbana.

Assim, os "cidadãos", na Grécia Antiga, eram aqueles que tinham propriedade, e que, por isso, podiam ter acesso à cidade da Pólis, tida como centro de decisões e deliberações políticas e de reflexão filosófica. A própria palavra: "civilizado" é derivada de civitas, ou seja, refere-se àquele que vive nas cidades e tem acesso à participação política e ao pensamento filosófico-racional, que figuram como processos e relações produzidos próprios desse espaço. A industrialização, ocorrida a partir do século XVIII na Europa, potencializaria ainda mais a oposição entre rural e urbano, no que se refere ao acesso à educação formal, pois se tornava necessário educar para o trabalho industrial característico das cidades e do "mundo civilizado". O campo, por sua vez, ficaria excluído do projeto capitalista de educação na sociedade industrial que emergia. Dessa forma, é interessante notar que o "homem educado" da sociedade moderna seria conhecido como sinônimo de "homem civilizado", ou "polido", ao passo que designações depreciativas como as de "atrasado", "ignorante", “matuto", "xucro", "simplório", “peão", "caipira", etc., seriam associadas ao "homem do campo".

O meio rural pode ser, assim, definido como uma tradicional "área de exclusão", onde o sistema capitalista mantém formas arcaicas e extremadas de exploração da classe trabalhadora, com o desrespeito, até mesmo, aos direitos socialmente instituídos (dentre eles, o direito à educação, à saúde e à CLT, por exemplo), configurando uma "questão social agrária" bastante problemática.

Nota-se, portanto, que a relação entre educação e meio rural é tão paradoxal quanto a relação existente entre educação e velhice. Só se educa a quem supostamente terá alguma utilidade para a sociedade capitalista industrializada. Nessa lógica, o idoso analfabeto, o trabalhador rural e os demais povos do campo (cf. CALDART, 2008) não precisam ser educados. Conforme explica Vieira Pinto (2005):

A sociedade empreende a alfabetização de adultos fundamentalmente para poder integrá-los num nível superior de produção. Já temos dito que não se trata de dever moral de obras de caridade, e sim de uma imperiosa exigência social. A sociedade precisa educar seus adultos, desde que alcance um nível de desenvolvimento que torne incompatível a existência de segmentos marginalizados em seu seio, 
que podem aumentar a força de trabalho geral se forem convertidos (...) em trabalhadores letrados num nível alto de conhecimento. (...) Uma lei do desenvolvimento educacional é esta: a sociedade nunca desperdiça seus recursos educacionais (econômicos e pessoais), apenas proporciona educação nos estritos limites de suas necessidades objetivas. Não educa ninguém que não precise educar. (p. 102-103)

Talvez isso justifique, mesmo que parcialmente, a exclusão educacional que acomete, principalmente, a população com mais de 60 anos e os residentes nas regiões rurais. Por isso, acredito não ser possível desvincular EJA de alfabetização e, mesmo que indiretamente, de educação no campo. Enquanto não houver uma estrutura que garanta (realmente) acesso à educação pública nas regiões menos desenvolvidas do país, novos analfabetos estarão sendo gerados. A criança a quem não são dadas, hoje, condições mínimas de se educar, será o futuro adulto e idoso analfabeto.

Sabe-se, porém, que as iniciativas de "alfabetização em massa" que foram instituídas no país, principalmente na década de 1970, das quais o Movimento Brasileiro de Alfabetização (MOBRAL) foi o mais conhecido, estiveram carregadas de uma forte orientação político-ideológica, que se centrava na legitimação da ordem social instituída, regida pela "ditadura do grande capital", utilizando uma expressão do sociólogo Octávio lanni (1981). O estudo desenvolvido por Paiva (2003) mostra que, nessas ações de alfabetização empreendidas pelo MOBRAL, difundia-se, entre os alunos, uma ideologia de responsabilização pessoal pelo sucesso ou fracasso escolar obtido. Com isso, a própria condição de analfabetismo passou a ser estigmatizada e vista de forma depreciativa pela sociedade em geral, gerando, nos adultos e idosos que não sabiam ler e escrever, um sentimento de culpa e vergonha. Além disso, e de forma coerente aos propósitos de controle do governo militar, instituiu-se, via MOBRAL, um processo de adestramento e disciplinamento das camadas populares, no intuito de incitar nelas um nacionalismo alienado de "amor à pátria" e evitar a disseminação, entre elas, das "ideias subversivas" do comunismo/socialismo de base marxista.

Nos dias de hoje, o analfabetismo ainda é normalmente tratado como responsabilidade pessoal dos analfabetos. O Estado procura, ao máximo, se eximir dessa responsabilidade, atribuindo, primeiramente, à família - portanto, à esfera privada e pessoal - o dever de educar, conforme podemos ver na LDB (Lei 9394/96, artigo 2 \%). A educação de jovens e adultos (EJA), citada na LDB como alternativa educacional destinada "àqueles que não tiveram acesso ou continuidade de estudos no ensino fundamental e médio na idade própria" (Art. 37ㅇ), ainda é tratada como forma secundária de oferta educacional, e, principalmente, destinada aos "jovens e adultos trabalhadores". O idoso (aposentado, ex-trabalhador), por sua vez, nem sequer é citado nos parágrafos que compõem a EJA na atual LDB. 
Os altos índices de evasão dos programas de EJA são atribuídos, frequentemente, a fatores relacionados à vida pessoal, social e profissional dos alunos. Raramente são associados, contudo, à inviabilidade estrutural e metodológica dos programas, à sua ineficiência como alternativa educacional, à sua desconsideração da heterogeneidade dos participantes e ao desprezo pelos seus conhecimentos acumulados ao longo da vida e, ainda, como consequência do tradicional descaso do Poder Público e de muitos educadores para com os programas de EJA (GADOTTI, 2000).

Uma das principais críticas que podemos fazer à EJA é quanto à utilização da mesma metodologia de ensino para um público potencialmente heterogêneo no que se refere à faixa etária. Em uma mesma turma convivem, por exemplo, jovens de 18 anos com adultos de 40 e idosos de 70 anos. Não é necessário ser especialista em educação para perceber que cada um desses grupos de idade possui perspectivas e expectativas totalmente diferentes quanto à educação. Também é bastante óbvio que as experiências de vida dos mais velhos são bem mais vastas do que as dos mais jovens. Por isso, conforme destaca Arroyo (1996), uma metodologia de ensino adequada para o público adulto, que é a andragógica e não a pedagógica, deve considerar as experiências de vida, o conhecimento tácito no processo de aprendizagem, bem como o contexto sociocultural no qual vivem os alunos ("educação contextualizada", cf. definição de Caldart, 2008).

Contudo, vemos que, salvo raras exceções, os educadores que atuam na EJA geralmente não estão capacitados para esse tipo de prática, uma vez que os cursos de formação de professores (as chamadas licenciaturas) são centrados nas técnicas de ensino/aprendizagem da Pedagogia, geralmente destinadas à educação de crianças e jovens. A andragogia ainda é, para a imensa maioria dos educadores brasileiros, uma ilustre desconhecida (ARROYO, 1996) ${ }^{4}$.

Podemos dizer que, no atual contexto, o idoso é invisível na EJA, tal como a criança e a infância também não existiam na Idade Média, resgatando a abordagem de Ariès (1981).

Ainda com relação aos aspectos metodológicos, notamos que a LDB está longe de levar em conta outras realidades, diferentes daquela vivida nas cidades. Os pobres, os residentes das áreas rurais e os idosos continuam invisíveis às leis e políticas de educação no Brasil. Conforme destaca a educadora Roseli Caldart (2008), embora o problema da educação brasileira não seja apenas no campo, é aí que a situação se torna mais grave, pois além de desconsiderar a realidade escolar existente, que é bastante diferente da vivida nos grandes centros urbanos, sempre foi tratada pelo poder público com políticas compensatórias (de caráter paliativo), e sem um compromisso efetivo de adaptação da educação às peculiaridades do meio rural. Podemos pensar, ainda, que nas regiões rurais
4. É curioso como, em certos países desenvolvidos, em que 0 envelhecimento populacional já é tratado, há algum tempo, como um importante fenômeno sociodemográfico, a educação de adultos constitui uma realidade concreta e bem estruturada dentro dos sistemas educacionais, adquirindo notoriedade também como área acadêmica. A título de exemplo, podemos citar o Canadá. Quando estive na Universidade de Montreal em 2007, para a realização de um estágio de doutorado, percebi a existência de um "Departamento de Andragogia", vinculado ao Departamento de Educação desta universidade. 
é onde há maior necessidade de políticas de educação de adultos, especialmente as de alfabetização. Contudo, elas não ocorrem.

Tradicionalmente, a escola foi concebida como uma invenção da sociedade capitalista industrial em geral, e da cidade em particular, destinada a preparar as elites para governar e a camada popular para ser mão-de-obra (portanto governada). Por isso, o campo não se constituiu historicamente como espaço prioritário para ações institucionalizadas do Estado, através de diferentes políticas públicas e sociais, e nem de políticas econômicas de desenvolvimento local e regional. Nessa perspectiva, o campo é pensado numa relação "não-hegemônica" de educação, ou seja, que se situa à margem da perspectiva urbano-industrial da sociedade capitalista (CALDART, 2008).

O meio rural é então representado como um espaço caracterizado por uma realidade geográfica e uma formação histórico-cultural singulares aos sujeitos que o compõem, ou seja, camponeses, agricultores e extrativistas (assentados, sem terra, ribeirinhos), trabalhadores do campo (assalariados, meeiros, etc.), pescadores, quilombolas, indígenas e povos da floresta. Assim, o desprezo pela vida rural e suas peculiaridades, verificado nas leis e políticas educacionais, é análogo à exclusão histórica vivida pelos povos do campo no Brasil.

\section{O analfabetismo e os analfabetos: faces e fases da exclusão educacional}

O analfabetismo é um problema histórico no Brasil. Está atrelado ao seu passado como colônia de exploração, de economia agrícola, fundada no latifúndio e na monocultura para exportação. Também está conectado aos povos indígenas e aos negros africanos, explorados, aculturados e escravizados, e a quem não foi dada oportunidade de inserção na sociedade de classes (cf. FERNANDES, 2008). A própria escola pública, até a primeira metade do século $X X$, era restrita às classes privilegiadas.

Porém, o processo de expansão do ensino público não ocorreria uniformemente. As escolas iriam se concentrar, especialmente, nos espaços urbanos e regiões centrais das cidades, enquanto que o campo - ou zona rural - assumiria uma importância secundária nesse processo. Assim, a predominância das escolas públicas nas cidades e nos principais centros urbanos do país, bem como a ausência ou insuficiência de instituições escolares para atender às populações rurais, somado à histórica exclusão educacional vivenciada pelos povos do campo, iriam tornar o analfabetismo um problema essencialmente rural no Brasil. De forma análoga, as áreas consideradas menos desenvolvidas do território nacional, como a região Nordeste, por exemplo, comportariam a grande maioria da população analfabeta do país. 
Dentre os excluídos da educação, os idosos e adultos mais velhos figuram como os mais atingidos. As estatísticas censitárias revelam que os índices mais elevados de analfabetismo estão entre as faixas etárias mais velhas. A situação desses indivíduos se torna ainda pior pela inexistência, no Brasil, de políticas educacionais direcionadas à velhice e ao analfabetismo. Podemos dizer que a exclusão educacional vivenciada no campo e nos interiores dos estados do Nordeste, predetermina a maior incidência do analfabetismo entre as populações rurais, sobretudo nas coortes mais velhas. Sabe-se que pequenos municípios nordestinos, apesar de serem classificados como "urbanos" pelas estatísticas censitárias, na verdade possuem uma dinâmica de vida bem mais próxima da zona rural $^{5}$.

Há, também, especialmente na região Nordeste, a predominância do latifúndio como forma de propriedade da terra. A pesquisa de Ferraro (2009) mostra a relação existente entre latifúndio e analfabetismo no Brasil. Segundo o autor, quanto maior a concentração da propriedade da terra, maiores são os índices de analfabetismo observados em uma região. Isso justificaria a menor ocorrência desse problema social nos estados do Sul (Paraná, Santa Catarina e Rio Grande do Sul), a região do país onde houve menor concentração da terra ao longo da história.

O problema do analfabetismo que acomete as populações mais idosas tem relação direta com o fato de ser este um grupo social abandonado pelo Poder Público quanto ao estabelecimento de políticas educacionais. O fenômeno da exclusão educacional da população idosa nos leva a compreender o sistema educacional como uma estrutura burocrática criada com o fim de promover a formação e a qualificação da mão-de-obra jovem para o mercado de trabalho (urbano-industrial), atuando de maneira funcional ao sistema capitalista. Assim, como se sabe, a exclusão dos idosos do mercado de trabalho pré-determinaria a sua exclusão da esfera da educação.

As regiões nordestinas do semiárido do Rio Grande do Norte e da zona cacaueira do Sul da Bahia, consideradas nesta pesquisa, são historicamente conhecidas como áreas de exclusão social. Marcadas pela predominância do latifúndio, ambas as regiões se caracterizam por uma grande desigualdade social e uma elevada concentração de renda. A exclusão educacional aí verificada serve para ampliar ainda mais as diferenças sociais, criando uma elite letrada e culta, que contrasta com uma massa de indivíduos analfabetos e/ou pouco escolarizados.

Diz a Constituição de 1988 que todos os cidadãos têm direito à educação pública e gratuita, independente de idade, sexo, cor, nacionalidade ou qualquer outra diferença. Contudo, sabemos que a realidade é bem diferente. No que se refere aos idosos, o Censo de 2000 do IBGE mostrava que 39,2\% dos que tinham mais de 60 anos eram analfabetos. O Censo de 2010, por sua vez, revela que $26 \%$
5. Sobre isso, ver estudo de Veiga (2003): Cidades imaginárias: o Brasil é menos urbano do que se calcula. 
da população idosa brasileira é analfabeta. Quando consideramos as pessoas de 15 anos ou mais, em 2000, o índice de analfabetismo era de $13,63 \%$, passando a ser de 9,6\% em 2010.

A maior proporção de analfabetos concentra-se nos municípios nordestinos com até 50 mil habitantes. Nestes, 28\% da população de 15 anos ou mais é analfabeta. Nessas cidades, a proporção de idosos que não sabem ler e escrever chega a $60 \%$. O estado brasileiro onde há maiores índices de analfabetismo é Alagoas, seguido pelo estado do Piauí. Se considerada apenas a faixa etária acima dos 60 anos, o Piauí ocupa a vergonhosa primeira posição no analfabetismo: 55,9\% dos idosos piauienses não sabem ler e escrever. Em contrapartida, o melhor resultado foi observado nos estados do Sul do país, particularmente em Santa Catarina, onde apenas 4,1\% da população com 15 anos ou mais é analfabeta, segundo o Censo 2010.

Na região do semiárido nordestino, a taxa de analfabetismo das pessoas de 15 anos ou mais também foi bem mais elevada do que a média nacional, apesar de ter uma redução de 32,6\% em 2000, para 24,3\% em 2010. Entre os analfabetos residentes nessa região, $65 \%$ eram pessoas maiores de 60 anos de idade. Um dado interessante é que, dos 1.304 municípios brasileiros com taxas de analfabetismo iguais ou superiores a 25\%, 32 não ofereciam o programa Educação de Jovens e Adultos (EJA). A maioria deles estava no Nordeste. O município de João Dias (RN) apresentou o maior índice (38,9\%), seguido de Monte Santo (BA), com 35,6\% e São Brás (AL), com 34,7\%. Observa-se que países com um nível de renda per capita similar ao brasileiro contam, normalmente, com uma taxa de analfabetismo de $5,8 \%$. Assim, a taxa de analfabetismo brasileira é mais do que o dobro $(14,8 \%)$ desses países.

Com base nos números da PNAD, de 2001, vemos que, ao longo da década de 1990, a taxa de analfabetismo feminina passou a ser inferior à masculina. Isso indica que a taxa de analfabetismo das mulheres nascidas após a metade da década de 1960 é inferior à das coortes masculinas. Verifica-se, também, que a taxa de analfabetismo para a população negra é quase três vezes maior do que para a população branca, fazendo com que mais de $2 / 3$ dos analfabetos sejam negros. Podemos constatar, ainda, que a taxa de analfabetismo é bem maior entre as coortes mais velhas do que entre as mais jovens, com a taxa sendo seis vezes maior entre idosos de 55 a 64 anos (26\%), do que entre jovens de 15 a 24 anos (4\%). No que se refere ao nível de renda, verifica-se que quase a metade dos analfabetos encontra-se entre $25 \%$ mais pobres do país, enquanto que mais de $3 / 4$ vivem entre os $50 \%$ mais pobres.

A PNAD 2001 mostrou, também, que o analfabetismo na área rural (26\%) é 2,5 vezes maior do que a taxa da área urbana (9\%) e mais de cinco vezes maior 
do que a das áreas metropolitanas (5\%). Devido à elevada concentração de analfabetos na área rural, temos que mais de $1 / 3$ deles vivem em áreas rurais, embora menos de $1 / 6$ da população total brasileira viva nessas áreas. Em termos de diferença regional, as taxas de analfabetismo variam entre $28 \%$ em Alagoas e $4 \%$ no Rio de Janeiro, Santa Catarina e São Paulo. Enquanto que, em todos os estados do Nordeste, a taxa de analfabetismo está próxima ou acima de $20 \%$, em todos os estados das regiões Sul, Sudeste e Centro-Oeste, a taxa de analfabetismo é igual a $10 \%$.

Devido a uma maior concentração de analfabetos no Nordeste, temos que mais da metade (56\%) dos analfabetos do país vivem nessa região, embora a população local corresponda a um pouco mais de $1 / 4$ (27\%) do total brasileiro. Ao longo das duas últimas décadas, a queda do analfabetismo foi maior nas áreas mais pobres, levando a uma redução das disparidades regionais. Apesar disso, a taxa de analfabetismo no Nordeste é tão mais elevada que, mantida a velocidade de progresso atual, seriam necessários mais de 25 anos para que o Nordeste atingisse a situação atual do Sudeste. Enquanto que, para Alagoas atingir a situação atual do Rio de Janeiro, por exemplo, seriam necessários 34 anos, de acordo com as estimativas do IBGE (PNAD, 2001).

O relatório intitulado Síntese dos Indicadores Sociais de 2007 no Brasil, elaborado pelo IBGE, também mostra que o analfabetismo no país atinge 14,4 milhões de pessoas com 15 anos ou mais e está concentrado nas camadas mais pobres, nas áreas rurais, especialmente do Nordeste, entre os mais idosos, de cor preta e parda.

Analfabetismo no Nordeste: o caso do semiárido do Rio Grande do Norte Na região conhecida como semiárido nordestino - mais especificamente no interior do Estado do Rio Grande do Norte -, encontramos algumas das maiores taxas de analfabetismo do Brasil, verificadas principalmente entre a população com 60 anos ou mais. A Tabela 1 mostra os dados dos grupos de idade e os respectivos índices de analfabetismo, nos municípios de Mossoró, Angicos e Natal. Esses dados permitem analisar as diferenças entre capital e interior, no que se refere ao acesso à educação formal nas diferentes faixas etárias. Na cidade de Mossoró, os dados do IBGE mostram que, em todos os grupos de idade considerados, as taxas de analfabetismo são superiores às verificadas na capital do estado. No município de Angicos, podemos ver um cenário ainda pior que o de Mossoró, com índices de analfabetismo mais elevados em todos os grupos de idade, principalmente entre os adultos mais velhos e idosos. 


\begin{tabular}{|c|c|c|c|c|}
\hline \multicolumn{5}{|c|}{$\begin{array}{c}\text { Tabela } 1 \text { - População residente por nível de alfabetização, município e grupos de idade } \\
\text { (Rio Grande do Norte - Ano de 2000) }\end{array}$} \\
\hline $\begin{array}{c}\text { Municípios do } \\
\text { RN }\end{array}$ & $\begin{array}{l}\text { Grupos de } \\
\text { idades }\end{array}$ & $\begin{array}{c}\text { Pop. total por faixa } \\
\text { etária }\end{array}$ & $\begin{array}{c}\text { Não } \\
\text { Alfabetizados }\end{array}$ & $\begin{array}{l}\text { Porcentagem } \\
\text { alfabetizados }\end{array}$ \\
\hline \multirow{5}{*}{ Natal } & 10 a 14 anos & 72.195 & 5.294 & $7,33 \%$ \\
\hline & 25 a 29 anos & 59.253 & 4.673 & $7,88 \%$ \\
\hline & 35 a 39 anos & 55.275 & 5.616 & $10,16 \%$ \\
\hline & 45 a 49 anos & 35.554 & 4.824 & $13,56 \%$ \\
\hline & 60 anos ou mais & 56.269 & 17.438 & $31 \%$ \\
\hline \multirow{5}{*}{ Mossoró } & 10 a 14 anos & 23.487 & 1.883 & $8,01 \%$ \\
\hline & 25 a 29 anos & 18.040 & 2.224 & $12,32 \%$ \\
\hline & 35 a 39 anos & 16.832 & 2.975 & $17,67 \%$ \\
\hline & 45 a 49 anos & 9.336 & 2.317 & $24,81 \%$ \\
\hline & 60 anos ou mais & 16.510 & 7.988 & $48,38 \%$ \\
\hline \multirow{5}{*}{ Angicos } & 10 a 14 anos & 1.489 & 185 & $12,42 \%$ \\
\hline & 25 a 29 anos & 771 & 174 & $22,56 \%$ \\
\hline & 35 a 39 anos & 778 & 245 & $31,49 \%$ \\
\hline & 45 a 49 anos & 473 & 212 & $44,82 \%$ \\
\hline & 60 anos ou mais & 1.340 & 859 & $64 \%$ \\
\hline
\end{tabular}

Fonte: IBGE, Censo 2000.

É possível notar como as taxas de analfabetismo aumentam conforme diminui o nível de desenvolvimento urbano dos municípios, ou seja, quanto menos desenvolvido for o município, maiores serão as taxas de analfabetismo. Nas regiões menos urbanizadas do interior do Estado, como Angicos, encontramos taxas de $64 \%$ de analfabetismo na população idosa (com 60 anos ou mais), contra o índice de $31 \%$ observado em Natal para o mesmo grupo de idade. Na cidade de Mossoró, que é considerada o principal pólo de desenvolvimento urbano da região do semiárido potiguar, e a segunda maior cidade do Rio Grande do Norte (depois da capital), também há taxas elevadas de analfabetismo. Entre os idosos, $48,38 \%$ não são alfabetizados, um índice que, apesar de ser menor que o de Angicos, é bem mais alto do que o da capital do Estado e, também, do que a média nacional de analfabetismo dessa faixa etária (de 34,6\%).

É possível observar, também, que os índices de analfabetismo crescem proporcionalmente ao avanço da idade, nos três municípios considerados. Nas faixas etárias iniciais, como a de 10 a 14 anos, podemos ver, no máximo, 12,42\% de não alfabetizados em Angicos, contra 22,56\% na população de 25 a 29 anos e $44,82 \%$ na de 45 a 49 anos. Além disso, notamos que a variação de pontos percentuais entre os três municípios também cresce conforme o avanço da idade. Considerando os números de Natal (menores índices) e Angicos (maiores índices), temos uma diferença de 5,09 pontos na população de 10 a 14 anos, 
que passa a ser de 14,68 no grupo de 25 a 29 , de 21,33 entre os de 35 a 39, de 31,26 na população de 45 a 49 e de 33 entre os com 60 anos ou mais.

Isso revela que, em comparação com os outros grupos de idade, a população idosa é a mais atingida pelo analfabetismo, principalmente nas regiões menos urbanizadas do interior do estado, o "sertão" do semiárido potiguar. Isso retrata a situação de miséria social dessa região, no que se refere à exclusão educacional que atinge todas as faixas etárias, mas principalmente as mais idosas, configurando um problema social grave e, muitas vezes, invisível à sociedade e ignorado pelo Poder Público. Nossos padrões culturais são condicionados a associar educação e alfabetização somente à infância, esquecendo que a velhice também é uma fase da vida humana que apresenta demandas educacionais.

Sabemos que o analfabetismo impede qualquer acesso à cultura escrita e a um conjunto de informações necessárias ao exercício da cidadania e, por isso mesmo, as ações de alfabetização são emergenciais. Contudo, sabemos que a Lei de Diretrizes e Bases da Educação Nacional - LDB (Lei 9394/96), nem sequer cita a velhice como uma etapa da vida humana que necessita de maior atenção do Estado no que se refere à educação e alfabetização. A LDB também não cita o termo analfabetismo ao longo dos seus 92 artigos. O Estatuto do Idoso (Lei 10.741/03), por sua vez, apesar de reunir leis específicas da velhice, não trata do problema do analfabetismo que atinge os idosos, em nenhum dos itens referentes à educação (Cap. V, artigos de 20 a 25). Ao contrário, ignora-o totalmente.

Por outro lado, e de maneira contraditória, o Estatuto incentiva a criação de universidades abertas da terceira idade (UNATI), que têm um caráter essencialmente elitista e paliativo, sendo voltadas principalmente ao desenvolvimento de atividades de esporte e lazer, que visam atender demandas de uma elite de idosos. As UNATI não podem, portanto, ser consideradas como iniciativas relevantes diante da situação de analfabetismo vivida por muitos idosos das classes populares (PERES, 2005).

A conexão estabelecida entre o analfabetismo e o problema da educação no campo é, no entanto, evidente. E isso não só pela grande parcela de analfabetos que residem nas áreas rurais, mas também em decorrência da precariedade que acompanha esse tipo de educação na sociedade brasileira. Apesar de ser constitucional, o direito à educação ainda não foi totalmente universalizado. As populações rurais, os pobres, os negros, indígenas e também os idosos são grupos historicamente excluídos do processo educacional. Por isso a existência das chamadas "políticas afirmativas", que visam atuar de forma compensatória frente à exclusão, no intuito de minimizá-la.

A dificuldade de acesso aos direitos sociais (e trabalhistas) no campo é um 
6. Conforme mostra o estudo de Delgado \& Cardoso Jr. (1999), demorou praticamente meio século, desde a promulgação da Lei Eloi Chaves, em 1923, que regulamentou a criação das Caixas de Aposentadorias e Pensões (CAP) dos trabalhadores urbanos, para que se inaugurasse no Brasil um sistema de assistência social aos idosos e inválidos do setor rural. O Programa de Assistência ao Trabalhador Rural e o Fundo de Assistência e Previdência do Trabalhador Rural (PRORURAL/FUNRURAL), seriam implantados em 1971 e universalizados somente em 1992. Isso comprova que, entre os trabalhadores rurais, o direito à Previdência Social é bastante tardio. problema histórico no Brasil, haja vista o seu caráter tardio e ainda precário ${ }^{6}$. Caldart (2008) lembra que, embora o problema da educação brasileira não seja apenas no campo, é aí que a situação se torna mais grave. Além de desconsiderar as necessidades escolares efetivas da vida camponesa, que é essencialmente diferente da vida urbana, a educação praticada no campo é tida pelo Estado como secundária, não havendo um compromisso efetivo de adaptação (ou "contextualização") à realidade do meio rural.

\begin{tabular}{|c|c|c|c|c|}
\hline Brasil e UF & $\begin{array}{l}\text { Situação de } \\
\text { domicílio }\end{array}$ & $\begin{array}{l}\text { População } \\
\text { total }\end{array}$ & $\begin{array}{c}\text { Não } \\
\text { alfabetizados }\end{array}$ & $\begin{array}{l}\text { Porcentagem não } \\
\text { alfabetizados }\end{array}$ \\
\hline \multirow{3}{*}{ Brasil } & Total & 153.486 .617 & 24.093 .776 & $16 \%$ \\
\hline & Urbana & 125.175 .892 & 15.391 .771 & $12,30 \%$ \\
\hline & Rural & 28.310 .725 & 8.702 .005 & $22,70 \%$ \\
\hline \multirow{3}{*}{$\begin{array}{l}\text { Rio Grande do } \\
\text { Norte }\end{array}$} & Total & 2.498 .980 & 650.371 & $26 \%$ \\
\hline & Urbana & 1.838 .818 & 394.005 & $21,40 \%$ \\
\hline & Rural & 660.162 & 256.366 & $38,80 \%$ \\
\hline
\end{tabular}

Fonte: IBGE, Censo 2000.

A Tabela 2 apresenta números que exigem uma reflexão mais cuidadosa. Uma análise comparativa entre os contextos rural e urbano, acerca das condições de alfabetização no Brasil e no Rio Grande do Norte, revela que há um maior percentual de analfabetos no campo, apesar de, em números absolutos, ser bem maior a quantidade de não alfabetizados vivendo nas áreas urbanas. Fato semelhante pode ser observado, também, na Tabela 1, onde a quantidade de não alfabetizados vivendo na região metropolitana de Natal é consideravelmente superior à verificada em Mossoró e em Angicos, cidades do interior do estado.

Nesse mesmo sentido, levando-se em conta a totalidade do território nacional, a Tabela 2 mostra que os números absolutos de não alfabetizados da zona urbana (que giram em torno de 15,4 milhões) é quase o dobro dos verificados na zona rural (aproximadamente de 8,7 milhões). Já o percentual de analfabetos das regiões rurais $(22,7 \%)$ supera e muito o da zona urbana $(12,3 \%)$. Merece destaque, também, a pior situação em que se encontra o Rio Grande do Norte em comparação à realidade brasileira. Notamos que esse Estado apresenta dez pontos percentuais a mais em sua taxa de analfabetismo total (de 26\%), quando comparada à taxa média nacional (de 16\%).

Impasses como os observados nas Tabelas 1 e 2 podem ser justificados considerando a maior densidade demográfica que normalmente é verificada nas cidades. O êxodo rural, que acompanhou o processo de industrialização, acelerou os movimentos de urbanização no Brasil, especialmente na segunda metade 
do século XX. Além disso, estudos como o de Veiga (2003) revelam a dificuldade de se diferenciar com precisão as áreas rurais das áreas urbanas, em virtude da utilização de métodos "inadequados" e "simplistas" de classificação pelos organismos oficiais, como o IBGE. Como consequência, muitas áreas consideradas "urbanas" no Censo - principalmente entre os municípios com menos de 50 mil habitantes -, possuem, na verdade, um perfil essencialmente "rural". Para o autor, caso se levasse em conta critérios mais precisos e abrangentes de análise, como dinâmica econômica, infraestrutura de serviços, níveis de desenvolvimento urbano e regional, etc. (tal como é feito em países europeus como a França, por exemplo), o retrato demográfico do Brasil seria menos "urbano" do que aparenta ser nas estatísticas oficiais.

Apesar dessas contradições, observa-se, na Tabela 2, que a diferença entre rural e urbano no estado do Rio Grande do Norte é notadamente exacerbada. No que se refere à proporção de pessoas não alfabetizadas, ela atinge 17,4 pontos percentuais, ou seja, sete pontos a mais do que a diferença verificada a nível de Brasil (de 10,4 pontos percentuais). Essa realidade se deve à elevada concentração de renda e aos níveis alarmantes de miséria social existentes na região semiárida, que, inclusive, possui um dos piores índices de desenvolvimento humano (IDH) do país. Sabe-se que os municípios das regiões semiáridas, que figuram como os mais afetados pelos efeitos da desertificação, são também os mais defasados no que se refere ao desenvolvimento humano e social. Eles são quase 40\% (397) dos 1.000 de menor IDH. Os que ficam em áreas sub-úmidas secas - que se encontram no segundo grau na escala do índice de aridez - representam pouco menos de um quinto (190) do grupo dos piores. Por sua vez, os que se situam nos arredores desses climas correspondem a quase $13 \%$ (128) dos mil com menor IDH ${ }^{7}$.

Diante desse quadro alarmante, autores como Silva (2007) defendem a necessidade do estabelecimento de políticas públicas específicas, direcionadas à promoção do desenvolvimento social e humano da região semiárida e tendo como fim a redução da desigualdade. Para o autor, as políticas públicas destinadas ao semiárido nordestino sempre estiveram, ao longo da história, focadas majoritariamente nos seus aspectos climáticos e físicos, tal como o combate à seca, ignorando ou relegando ao segundo plano as questões sociais, tal como o acesso à educação.

Dentre os municípios do Alto Oeste do Rio Grande do Norte apresentados pela Tabela 3 (que também integram a região semiárida), vemos que, de acordo com os números do último Censo (de 2010), em nenhum deles a população total ultrapassa os 50 mil habitantes. De um mínimo de 2.980 habitantes no município de Água Nova (o menos populoso), até o máximo de 27.745 habitantes, no município de Pau dos Ferros (tido como a capital regional), verifica-se que a 
média de população desses municípios se encaixa perfeitamente no que Veiga (2003) vai chamar de "cidades imaginárias".

\begin{tabular}{|c|c|c|c|}
\hline Município & Total & Não-alfabetizadas & Taxa de analfabetismo \\
\hline Água Nova & 238 & 178 & $74,79 \%$ \\
\hline Alexandria & 1.639 & 1.063 & $64,86 \%$ \\
\hline Doutor Severiano & 634 & 445 & $70,19 \%$ \\
\hline Encanto & 577 & 324 & $56,15 \%$ \\
\hline Francisco Dantas & 321 & 193 & $60,12 \%$ \\
\hline Itaú & 544 & 260 & $47,79 \%$ \\
\hline José da Penha & 705 & 459 & $65,11 \%$ \\
\hline Marcelino Vieira & 936 & 571 & $61,00 \%$ \\
\hline Paraná & 343 & 250 & $72,89 \%$ \\
\hline Pau dos Ferros & 2.452 & 1.250 & $50,98 \%$ \\
\hline Portalegre & 788 & 434 & $55,08 \%$ \\
\hline Rafael Fernandes & 446 & 239 & $53,59 \%$ \\
\hline Riacho da Cruz & 332 & 134 & $40,36 \%$ \\
\hline Riacho de Santana & 476 & 201 & $42,23 \%$ \\
\hline São Francisco do Oeste & 310 & 212 & $68,39 \%$ \\
\hline São Miguel & 2.274 & 1.387 & $60,99 \%$ \\
\hline Severiano Melo & 747 & 447 & $59,84 \%$ \\
\hline Total & 13.762 & 8.047 & $58,47 \%$ \\
\hline
\end{tabular}

Senão, vejamos. Qual nível de urbanização teria, por exemplo, uma cidade como Água Nova, ou mesmo Pau dos Ferros? Obviamente que é muito desproporcional comparar esse perfil de "área urbana" com o de megacidades do interior de São Paulo, como Campinas, que já ultrapassou o índice de um milhão de habitantes. Essa comparação extremada, contudo, se faz necessária exatamente para percebermos o grau de imprecisão inerente às classificações de "urbano" e "rural" que são convencionalmente adotadas pelo IBGE.

Dessa forma, certamente municípios como Água Nova, com quase $75 \%$ de idosos não alfabetizados, possuiriam um perfil muito mais próximo da zona rural do que da zona urbana, no que se refere aos problemas de acesso à educação, à infraestrutura de serviços urbanos e à própria dinâmica de vida.

\section{Analfabetismo no Nordeste: o caso da região cacaueira do Sul da Bahia}

Conforme mostra o Censo 2010, especialmente nos Indicadores Sociais Municipais, a Bahia é o estado brasileiro que possui a maior população de analfabetos, em números absolutos. Ou seja, a quantidade de analfabetos nesse estado é a maior do Brasil, totalizando aproximadamente 1,73 milhões de cidadãos. Quando se considera o critério etnia, os piores números estão entre os negros $(17,9 \%)$, pardos $(17,1 \%)$ e indígenas $(18,9 \%)$. A população branca e amarela apresenta as menores taxas, sendo de $14,3 \%$ e $15 \%$, respectivamente. 
Seguindo uma tendência dos estados nordestinos, os índices de analfabetismo verificados entre a população baiana também são elevados entre as populações rurais mais idosas e do sexo feminino. Os dados da Tabela 4, obtidos na PNAD de 2008 , revelam que $74,1 \%$ das mulheres de 60 anos ou mais, residentes na zona rural, são analfabetas, contrastando com a taxa de $38 \%$ (ou seja, quase a metade) entre os integrantes da mesma categoria de idade e sexo que residem nas áreas urbanas. A situação dos homens de 60 anos a mais é análoga à das mulheres, porém um pouco menos precária, sendo de $32,7 \%$ de analfabetos na zona urbana e de $65,4 \%$ na zona rural.

\begin{tabular}{|l|l|l|l|l|}
\hline \multicolumn{6}{|c|}{ Tabela 4 - Percentual de analfabetismo por grupos de idade, sexo e situação de domicílio } \\
Bahia - Ano de 2008)
\end{tabular}

Fonte: IBGE-PNAD - Anuário Estatístico da Bahia, 2009.

Outro fato preocupante, que pode ser observado na Tabela 4, é o alto percentual de analfabetos com idade entre 5 e 9 anos, principalmente no campo, que supera os $50 \%$, entre os homens e entre as mulheres. Isso demonstra que as crianças continuam não tendo acesso à escola, fenômeno que causa a reprodução do analfabetismo também entre as novas gerações, derrubando a tese de que o problema se restringe à população mais velha, tal como defendia, dentre outros, o ex-senador e antropólogo Darcy Ribeiro ${ }^{8}$.

Conforme se observa, o analfabetismo não é somente um "problema de velhos", mas também afeta outros grupos de idade. Ele é, sem dúvida, um problema que está atrelado à situação de miséria social vivida, sobretudo, pelas populações rurais no país, pelos negros, pardos e indígenas, e pela população de baixa renda, principalmente na região Nordeste. O problema do analfabetismo se projeta, essencialmente, como uma questão social que envolve as dificuldades de acesso à educação, um impasse histórico no Brasil ainda a ser solucionado (sabe-se lá quando...), dada a inexistência de políticas públicas a ele relacionadas.

Diante dos dados apresentados, podemos afirmar que o analfabetismo no estado da Bahia é um problema que afeta mais diretamente as mulheres idosas, sobretudo as que residem nas áreas rurais, apesar de atingir também os homens, os que vivem na zona urbana, os idosos e não idosos. Assim, nota-se que a exclusão educacional abrange, além das diferenças geracionais, também diversidades relativas a gênero e localização geográfica (rural/urbana), que se aglutinam num todo composto e complexo de exclusão social e educacional.
8. “Quem pensar um minuto que seja sobre o tema, verá que é óbvio que quem acaba com o analfabetismo adulto é a morte. Esta é a solução natural. Não se precisa matar ninguém, não se assustem! Quem mata é a própria vida que traz em si o germe da morte. Todos sabem que a maior parte dos analfabetos está concentrada nas camadas mais velhas e mais pobres da população. Sabe-se, também, que esse pessoal vive pouco, porque come pouco. (...) Porém, se se escolarizasse a criançada toda, e se o sistema continuasse matando os veIhinhos analfabetos com que contamos [sic], aí pelo ano 2000 não teríamos mais um só analfabeto. Percebem agora onde está o nó da questão?" (Darcy Ribeiro, em palestra proferida na solenidade de abertura da 29a Reunião Anual da SBPC de 1977, em São Paulo. Apud ROMÃO, 2007, p. 42). 
Tais recortes - de gênero, idade e moradia, nesse caso - servem para melhor definir e delimitar os sujeitos que se encontram em situação de miséria social e que, em consequência disso, necessitariam da ação do Estado na forma de políticas sociais. Contudo, apesar do caráter de urgência que acompanha o problema, nada de concreto tem sido feito pelo Poder Público para promover a superação (real) da condição de exclusão e miséria social vivida por muitos. Ações como "Bolsa-Escola" e "Bolsa-Família", proclamadas aos quatro ventos pelo atual governo federal, como responsáveis pela melhoria (aparente) de renda da população, especialmente nas regiões Nordeste e Norte do país, não passam, na verdade, de medidas paliativas, que não promovem uma mudança estrutural e qualitativa nas condições de vida e no acesso aos direitos sociais.

\begin{tabular}{|l|l|l|l|l|l|}
\hline \multicolumn{6}{|c|}{ Tabela 5 - Escolas com EJA por município, localização e dependência administrativa } \\
(Bahia - Ano de 2008) \\
\hline Municípios & Total & $\begin{array}{l}\text { Urbana } \\
\text { estadual }\end{array}$ & $\begin{array}{l}\text { Urbana } \\
\text { municipal }\end{array}$ & $\begin{array}{l}\text { Rural } \\
\text { estadual }\end{array}$ & Rural municipal \\
\hline Ilhéus & 46 & 18 & 13 & 02 & 13 \\
\hline Itabuna & 49 & 15 & 29 & 00 & 05 \\
\hline Fonte: IBGE - Anuário Estatístico da Bahia, 2009.
\end{tabular}

Ao considerarmos os dados da Tabela 5, que mostra a quantidade de escolas que oferecem cursos na modalidade de educação de jovens e adultos (EJA) em dois municípios do Sul da Bahia - Ilhéus e Itabuna -, também podemos verificar que a situação da zona rural é mais problemática do que a da zona urbana, seguindo uma tendência nacional. Conforme mostra Ferraro (2009), ao longo da histórica brasileira, questões como o acesso à escola e a permanência nela sempre foram marcadas pela forte disparidade entre campo e cidade, com prejuízo evidente do primeiro. Portanto, é no campo onde mais se intensifica a exclusão educacional e social, apesar de o problema da educação não se limitar ao campo, como bem observa Caldart (2008). É na zona rural, também, que haveria a necessidade de mais escolas públicas, principalmente as de EJA, haja vista o elevado índice de analfabetismo entre idosos e adultos mais velhos. Contudo, a política pública de EJA na região, bem como em todo o estado, continua extremamente deficitária, precária, quando não inexistente. Não há na Bahia uma política pública de caráter efetivo e permanente de combate ao analfabetismo, fazendo com que o problema se perpetue ad infinitum e levando o estado a ocupar o primeiro lugar do país em números absolutos de analfabetos no último Censo (2010).

De acordo com a Tabela 5, a quantidade de escolas públicas estaduais de EJA existentes na zona urbana é muito maior do que as da zona rural, em ambos os municípios. Em Ilhéus, há 18 (dezoito) escolas na zona urbana, contra apenas 
2 (duas) na zona rural. Em Itabuna, por sua vez, há 15 escolas estaduais na zona urbana e nenhuma na zona rural. Na esfera municipal, há em Ilhéus a mesma quantidade de escolas nas zonas urbana e rural, num total de 13 (treze). Já em Itabuna, são 29 (vinte e nove) escolas na zona urbana, contra 5 (cinco) na rural.

Conhecida como "zona cacaueira", a área que engloba os municípios de Ilhéus e Itabuna é marcada por uma forte presença da agricultura de exportação, principalmente relacionada à produção do cacau. Isso quer dizer que a atividade agrícola tem sido de grande importância econômica para a região, principalmente a partir da produção do cacau (primeira metade do século XX). Contudo, nem mesmo a crescente importância econômica atrelada à produção agrícola fez com que os governos municipais e o estadual investissem na construção de escolas públicas em quantidade suficiente na zona rural. E como é predominante nas áreas rurais, a região cacaueira do Sul da Bahia passou a se constituir por índices elevados de analfabetismo e exclusão educacional e social, composta por uma forte concentração da renda e da propriedade (latifúndio).

Sabe-se que há forte presença do negro nessa região, marcada pela extensa utilização da mão-de-obra escrava. No entanto, os negros libertos da escravidão não tiveram condições de acesso aos direitos sociais, como educação, e nem à pequena propriedade familiar, como ocorreu no Sul do país. Isso seria essencial para torná-lo cidadão. Conforme ressalta Florestan Fernandes (2008), os escravos brasileiros foram apenas "soltos" numa sociedade essencialmente excludente e desigual, sem que obtivessem qualquer amparo social e/ou econômico da parte do Poder Público, em ações que pudessem compensar sua degradante condição de ex-escravo. Essa população teve de conviver, agora como mão-deobra "livre", junto a uma realidade extremamente hostil à sua presença e condição (de ex-escravo).

\begin{tabular}{|l|l|}
\hline \multicolumn{2}{|c|}{$\begin{array}{c}\text { Tabela 6: Composição étnica da população a nível estadual } \\
\text { (Bahia - Ano de 2006) }\end{array}$} \\
\hline Cor/raça & Porcentagem \\
\hline Pardos & $63,4 \%$ \\
\hline Brancos & $20,3 \%$ \\
\hline Negros & $15,7 \%$ \\
\hline Amarelos ou indígenas & $0,6 \%$ \\
\hline
\end{tabular}

Fonte: IBGE - PNAD, 2006.

Sabe-se que a Bahia é o centro da cultura afro-brasileira e que a maior parte da sua população é de descendência africana. A Tabela 6 revela a predominância de pardos, uma etnia que pode comportar o mulato, caboclo e cafuzo, resultantes do processo de miscigenação racial. Juntamente com os negros, tem-se que $79,1 \%$ da população baiana é composta por "não-brancos". A forte presença de negros e afrodescendentes contribui massivamente para engrossar os índices de analfabetismo e miséria social desse estado nordestino. Conforme já 
mostramos, os números do IBGE (Censo 2010) revelam que as piores taxas de alfabetização do estado estão entre a população negra e parda. No campo, comunidades quilombolas, também chamadas de "comunidades rurais negras", dividem espaço com assentamentos da reforma agrária (MST e outros) e com aldeias indígenas, configurando um espaço rural bastante heterogêneo e complexo do ponto de vista sociocultural.

Assim, em síntese, podemos dizer que a exclusão educacional verificada na Bahia tem, fundamentalmente, caráter étnico/racial, de classe socioeconômica e de localização geográfica. Os analfabetos desse estado são herdeiros diretos do seu passado escravocrata, marcado pelo latifúndio como propriedade rural e pelas práticas predatórias frente às terras indígenas. Em contraste, nos municípios do Sul da Bahia, mas especialmente em Ilhéus (que é mais antiga), podemos ver o caráter pomposo das elites rurais, descendentes dos fazendeiros produtores do cacau (os "coronéis"), reconhecidos como as principais forças políticas e econômicas da região. Esses representantes das elites locais articularam politicamente a criação de instituições públicas de pesquisa e ensino, diretamente ligadas à produção do cacau, como a Comissão Executiva do Plano da Lavoura Cacaueira (CEPLAC), mantida pelo governo federal, e a Universidade Estadual de Santa Cruz (UESC), ex-universidade privada, hoje mantida pelo governo estadual.

Dessa forma, seria no mínimo ingênuo (e mesmo contraditório) esperar medidas de redução da miséria social na região que fossem de iniciativa dessas duas instituições públicas, uma federal e outra estadual, que são diretamente ligadas às elites tradicionais. Ambas têm relação direta com a melhoria e recuperação da lavoura cacaueira, especialmente no combate aos problemas decorrentes da "vassoura-de-bruxa", um tipo de fungo que destruiu grande parte da produção na década de 1990, levando muitos fazendeiros à falência. Na UESC, por exemplo, o curso de maior tradição é o de agronomia, seguido pelo de medicina. As áreas de humanas e de educação/licenciatura são ainda as mais frágeis da instituição, ocupando uma importância secundária em relação às áreas de biológicas, exatas e tecnológicas. Todas as áreas, contudo, são extremamente carentes no desenvolvimento de políticas de extensão que possam atender às demandas da comunidade local, não contando, nem mesmo, com um hospital universitário e uma residência estudantil, ações consideradas fundamentais na política de permanência dos estudantes nas universidades públicas.

\section{Considerações Finais}


Entre as duas regiões nordestinas aqui analisadas - o semiárido do Rio Grande do Norte e a zona cacaueira do Sul da Bahia -, há semelhanças e diferenças. Ambas são regiões em que predomina o latifúndio, a concentração de renda é uma gritante desigualdade social, com a existência de elites tradicionais rurais de grande poder e influência política e institucional, tidas como responsáveis pelo "desenvolvimento" econômico dessas regiões, ou seja, pela sua industrialização e urbanização. Quanto às diferenças, podem ser notadas, especialmente no que se refere à composição étnica da população, uma maior presença de negros e pardos na Bahia, em virtude da utilização da mão-de-obra escrava nesse estado, e um maior nível de "branqueamento" no Rio Grande do Norte, onde a escravidão negra foi menos significativa. Essas diferenças e semelhanças interferem, direta ou indiretamente, no grau de exclusão educacional vivenciado por sujeitos sociais diversos, dentre os quais os idosos.

Esse artigo analisa a relação entre velhice e analfabetismo, considerando a inexistência de políticas públicas efetivas de educação voltadas a esse problema social, que, na maioria das vezes, torna-se invisível à sociedade. E essa falta de indignação pública (e política) diante da exclusão social que atinge os idosos é legitimada pela dissociação estrutural e histórica entre velhice e educação, que foi exacerbada pelo sistema capitalista. O velho não é visto pela sociedade como sujeito passível de ter respeitado (e exercer) o seu direito à educação, mesmo sendo este garantido pela nossa Carta Magna, a Constituição de 1988. Como entender tal processo? Vejamos o que a Sociologia (ou melhor, as "Sociologias") tem a contribuir nessa compreensão.

A relação entre papéis sociais e níveis de maturidade, analisada pela Sociologia das Gerações, pode servir como tentativa de explicação dessa relação autoexcludente entre velhice e educação em nossa sociedade. A noção do adulto como indivíduo "quase completo" no que se refere à formação/qualificação, contrasta com as ideias de infância e juventude como fases em que o ser é "incompleto", ou seja, está em processo de construção de sua identidade e individualidade. E isso justificaria a importância da educação escolar para a criança e o jovem "em formação". Ao adulto, restaria apenas o "aperfeiçoamento" (ou "atualização") dos seus conhecimentos, sobretudo profissionais. Os cursos técnicos e o ensino superior caberiam bem adequadamente, portanto, à fase adulta da vida. Se a criança e o jovem são "educados", o adulto, por outro lado, é "qualificado" para o trabalho. Já o idoso, por sua vez, é visto como indivíduo "decadente", "obsoleto", de identidade e papel social não só já cristalizados, como em vias de serem "abandonados" pela morte (social/profissional ou biológica/física). Nesse ideário, que está mais próximo do funcionalismo, nada justificaria uma "educação para a velhice", posto que, pela lógica, seria um desperdício de atividade social ou institucional (MOTTA, 2010). 
Émile Durkheim (2001) estuda, no seu conhecido ensaio Educação e Sociologia, a lógica geracional que permeia o processo educacional nos diversos tipos de sociedades humanas. Para ele, regra geral, cabe às gerações mais antigas e com maior nível de maturidade a função de transmitir aos novos membros da sociedade os valores que os transformariam, de sujeitos antissociais e egoístas, em sujeitos coletivos, sociais e altruístas, tornando-os, dessa forma, aptos para a vida em sociedade, que é regida pela solidariedade. Nota-se que a visão durkheimiana de educação, apoiada no positivismo, assume uma perspectiva determinista do fenômeno educacional: a de que os mais velhos e maduros só ensinam, enquanto que aos mais jovens e imaturos, caberia somente aprender e "se socializar". Os idosos e adultos mais velhos são, na qualidade de avós e pais, apenas "mestres" e nunca "discípulos". Assim, na perspectiva durkheimiana da Sociologia da Educação, não há lugar para a velhice no processo educacional, na condição de sujeito a ser educado. Ao contrário, o velho é somente aquele que educa.

A Sociologia do Trabalho, por sua vez, traz à tona a questão da qualificação profissional, que se encontra diretamente atrelada ao fenômeno educacional na sociedade capitalista. $O$ taylorismo/fordismo imprimiria na sociedade uma ideologia centrada no adestramento da força de trabalho, que deveria necessariamente perpassar pela "aprendizagem" de uma disciplina rígida, fundamental para a execução de atividades de trabalho com tempos e movimentos precisos, bem como pela super-especialização das funções e qualificações profissionais, necessária ao planejamento do processo de produção. Nota-se aqui um fenômeno natural de renovação da força de trabalho. 0 trabalhador que envelhece deve, necessariamente, ser substituído, porque perde em precisão e agilidade, em virtude das perdas biopsicossociais decorrentes do processo de envelhecimento. Além disso, os conhecimentos necessários à produção, envoltos na

9. Cf. Paranhos (2010) e Peres (2004). tecnologia, renovam-se rapidamente. 0 trabalhador idoso torna-se, portanto, "desatualizado" e "obsoleto".

$\mathrm{Na}$ acumulação flexível, o processo de individualização da carreira profissional empreendido pelo sistema torna a ideia de competência mais importante do que a de qualificação. Apesar de bastante vaga e imprecisa, a competência passa a reger as relações de trabalho e a justificar o sucesso ou fracasso profissional obtido pelos sujeitos. A "culpa" por fracassar ou prosperar passa a ser unicamente do indivíduo, da sua "competência" e da sua "empregabilidade". É desse modo que se cria uma vinculação direta entre educação e sucesso profissional, educação e qualificação, educação e empregabilidade, que se torna o eixo da relação entre trabalho e educação, e que integra a "teoria do capital humano", que concebe a educação como formadora de recursos humanos, peças fundamentais na geração e ampliação da riqueza. Nesse processo, a "educação 
para formação profissional", sobretudo na qualificação de profissionais de alto nível, sobrepõe-se ao caráter social da educação como direito constitucional, que é extensivo a todos os cidadãos, indistintamente (PARANHOS, 2010).

Diante de forças econômicas tão poderosas no comando, qual prioridade poderia ser almejada pela educação popular, pela EJA e pelos programas de alfabetização, principalmente de idosos, tidos como mão-de-obra ultrapassada e obsoleta?

Ainda mais considerando que boa parte desses idosos brasileiros não-alfabetizados, que necessitariam de políticas educacionais, reside nas áreas rurais, sobretudo na região Nordeste, é evidente que o Estado e a iniciativa privada jamais dariam a prioridade necessária a uma questão social de tamanha envergadura. Além de ser a mesma dotada de um inegável obscurantismo, que a faz demandar, até mesmo, certa sensibilidade sociológica (ou antropológica) para ser compreendida em todas as suas nuanças. A Sociologia Rural estabelece que o caráter patriarcal e patrimonialista da sociedade brasileira configura de forma ampla a sua identidade. Em Raízes do Brasil, o historiador Sérgio Buarque de Holanda (1995) constrói o tipo ideal do "homem cordial", para caracterizar a identidade universal do povo brasileiro. Essa cordialidade (exagerada) tem relação direta com as nossas "raízes rurais", de antiga colônia de exploração, de economia centrada na produção agrícola, na monocultura de exportação, no latifúndio improdutivo. Assim, aprendemos a ser cordiais no interior de uma cultura que estimula a disciplina e a obediência passiva, a subserviência e o caráter servil como qualidades, a serem apreendidas pelos subalternos em uma sociedade de tipo autoritária.

Raymundo Faoro (2008), ao analisar a formação histórica do patronato brasileiro, percebe bastante bem os elementos patriarcais, tradicionais e patrimonialistas presentes no estilo de vida das classes dominantes, que se reproduzem e metamorfoseiam, de acordo com as peculiaridades do contexto social e histórico, no qual se encontram inseridas. As elites, assim, revezam-se e estabelecem intercâmbios entre a vida política e a empresarial, entre a rural (do latifúndio) e a urbana (da indústria e do comércio), etc. Assim, os "donos do poder" continuam os mesmos, desde a época do Brasil colônia. Eles somente se reinventam, a cada geração. Com esse "mandonismo" inerente à reprodução das elites políticas e econômicas na sociedade brasileira, não fica só difícil, mas sim impossível pensar na possibilidade de atender demandas das classes populares, principalmente as rurais. Não é à toa que o atraso é simbolicamente associado ao campo e ao "rural". Os direitos aí são sempre tardios. Até a própria palavra "cidadania" tem conexão etimológica com o urbano, com a "cidade", em detrimento do rural, o qual passa a ser visto como um "não-lugar", onde predomina a ausência. Assim, compreender o problema social do analfabetismo na velhice a partir 
da sua ocorrência (proporcionalmente maior) no campo remete à denúncia de um descaso histórico do Estado e das elites econômicas e políticas brasileiras para com os sujeitos sociais que vivem no campo e dele retiram o seu sustento através do trabalho.

Conforme mostra o estudo de Albuquerque Jr. (2000), o Nordeste como espaço geográfico de exclusão também deve ser pensado a partir da sua própria construção simbólica que ocorreria ao longo da história. Tal como o "rural" se processou em relação ao "urbano" na sociedade capitalista industrial, a identidade do Nordeste foi criada a partir da sua comparação com o Sudeste, especialmente São Paulo. Ficou também conhecido como o lugar da falta, da ausência, da precariedade, do "não lugar" da cidadania, do desrespeito aos direitos sociais e trabalhistas, da "não-urbanização", da "não-industrialização", da "não-educação", da "não-civilidade", enfim, da exclusão frente ao desenvolvimento padrão da sociedade capitalista.

É nesse cenário, "nordestino e rural", que a problemática do analfabetismo na velhice ganha recortes originalmente brasileiros, quando analisada a partir dos múltiplos olhares sociológicos que tentam explicar esse nosso imenso e complexo país.

Abstract: This paper analyzes the relationship between the old age and illiteracy in the Northeastern of Brazil, especially in two areas: the semi-arid region of Rio Grande do Norte and the area of southern Bahia cocoa. According to the IBGE 2010 census, in the Northeast there are higher rates of illiteracy in the country. The problem of illiteracy affects mainly older people, black and brown, female and living in rural areas. The relationship between landowners and illiteracy partly explains the higher incidence of this problem in the Northeast, where there is greater concentration of income and also the rural property. The absence in Brazil of education policies directed towards old age and illiteracy can be observed in the absence specific laws, such as Brazilian Law of Education and the old age and Statutes of the Elderly. Finally, the understanding of this issue from the perspective of sociology is a theoretical contribution relevant to educational studies. Keywords: Old age, Illiteracy, Adult Education, Educational Policy, Northeast

\section{Referências Bibliográficas}

ALBUQUERQUE JUNIOR, Durval. A invenção do Nordeste e outras artes. Recife/ PE, São Paulo/SP: Massangana: Cortez, 2000. 
ALTHUSSER, Louis. Aparelhos ideológicos de Estado. Rio de Janeiro: Graal, 1992.

ARANHA, Maria. Filosofia da educação. São Paulo: Moderna, 2006.

ARIÈS, Philippe. História social da criança e da família. Rio de Janeiro: Guanabara, 1981.

ARROYO, Miguel. "Educação básica, profissional e sindical: um direito do trabaIhador, um desafio para os sindicatos" In: Educação de jovens e adultos: relatos de uma nova prática. Belo Horizonte: Secretaria Municipal de Educação, 1996.

BEAUVOIR, Simone. A velhice: realidade incômoda. Rio de Janeiro: Nova Fronteira, 1990.

BOSI, Ecléa. Memória e sociedade: lembranças de velhos. São Paulo: Companhia das Letras, 2006.

BRASIL. Constituição Federativa, Brasília/DF, 1988.

CALDART, Roseli. "Por uma educação do campo: traços de uma identidade em construção" In: M. Arroyo, R. Caldart, M. Molina (orgs.). Por uma educação do campo. Petrópolis/RJ: Vozes, 2008.

DAMATTA, Roberto. Relativizando: uma introdução à antropologia social. Rio de Janeiro: Rocco, 1997.

DEBERT, Guita. A reinvenção da velhice: socialização e processos de reprivatização do envelhecimento. São Paulo: EDUSP/FAPESP, 2004.

DELGADO, Guilherme; CARDOSO Jr., José. "O idoso e a previdência rural no Brasil: a experiência recente da universalização" In: Texto para discussão n. 688, Brasília/DF: IPEA, 1999.

DIAS, Edmundo. "A liberdade (im)possível na ordem do capital: reestruturação produtiva e passivização", Textos Didáticos IFCH-UNICAMP, n. 29, 1999.

DUBAR, Claude. La socialisation: construction des identites sociales et professionnalles. Paris: A. Colin, 1995.

DURKHEIM, Émile. Educação e sociologia. Lisboa: Edições 70, 2001.

Estatuto do Idoso - Lei 10.741, de 2003.

FAORO, Raymundo. Os donos do poder: formação do patronato político brasileiro. São Paulo: Globo, 2008.

FERNANDES, Florestan. A integração do negro na sociedade de classes. São Paulo: Globo, 2008. 
FERRARO, Alceu. História inacabada do analfabetismo no Brasil. São Paulo: Cortez, 2009.

FRIGOTTO, Gaudêncio. A produtividade da escola improdutiva. São Paulo: Cortez, 1984.

Fundação Perseu Abramo. Idosos no Brasil: vivências, desafios e expectativas na 3a idade. Resultado da pesquisa publicado em 07/05/2007.

GADOTTI, Moacir. Perspectivas atuais do educador. Porto Alegre: Artes Médicas, 2000.

GEERTZ, Clifford. A interpretação das culturas. Rio de Janeiro: Livros Técnicos e Científicos, 2008.

HOLANDA, Sérgio.Raízes do Brasil. São Paulo: Companhia das Letras, 1995.

IANNI, Octávio. A ditadura do grande capital. Rio de Janeiro: Civilização Brasileira, 1981.

IBGE. Censo 2000 e 2010.

PNAD 2007 e 2001. Anuário Estatístico da Bahia, 2009.

INEP. Mapa do analfabetismo no Brasil. Brasília/DF, 2003. Panorama da educação do campo. Brasília/DF, 2007.

LDB. Lei n. 9394, de 1996.

MARX, Karl. O capital. Vol 1. São Paulo: Abril Cultural, 1983.

MORAES, Carmen. Diagnóstico da formação profissional - Ramo metalúrgico. São Paulo: Artchip, 1999, p. 15-27.

MOTTA, Alda. "A atualidade do conceito de gerações na pesquisa sobre o enveIhecimento". Revista Sociedade e Estado, Departamento de Sociologia da UnB, Brasília/DF, vol. 25, n. 2, maio/agosto, 2010, p. 225-250.

PAIVA, Vanilda. História da educação popular no Brasil. São Paulo: Loyola, 2003. PARANHOS, Michelle. "A política educacional para a formação dos trabalhadores e a especificidade do projeto capitalista brasileiro: o ideário educacional em função da (des)qualificação do trabalho" Revista Educação Profissional, Faculdade SENAC, Brasília/DF, vol. 36, n. 2, maio/agosto, 2010, p. 33-49. 
PERES, Marcos. "A educação de jovens e adultos e o analfabetismo entre idosos no semi-árido nordestino: velhice e exclusão educacional no campo" Revista de Educação e Ciências Humanas, Belo Horizonte/MG, n. 10, ano V, out, 2009.

. "A andragogia no limiar da relação entre velhice, trabalho e educação". Revista História Sociedade e Educação no Brasil (HISTEDBR), da Faculdade de Educação da UNICAMP, n. 20, dez., 2005, p. 20-27.

. "Empregabilidade versus envelhecimento: Qualificação, competência e discriminação por idade no trabalho". Revista de Educação Pública, Cuiabá/MT: EDUFMT, v. 13, n. 24, jul./dez., 2004, p. 94-110.

PINTO, Álvaro. Sete lições sobre educação de adultos. São Paulo: Cortez, 2005.

PNUD, 2005.

RAMOS, Marise. A pedagogia das competências: autonomia ou adaptação? São Paulo: Cortez, 2001.

ROMÃO, José. "Educação de jovens e adultos: problemas e perspectivas" In: M. Gadotti, J. Romão. Educação de jovens e adultos: teoria, prática e proposta. São Paulo: Cortez, 2007.

Secretaria Municipal de Educação de São Paulo. Reorganização da EJA: Educação de Jovens e Adultos, 2008.

VEIGA, José. Cidades imaginárias: o Brasil é menos urbano do que se calcula. Campinas/SP: Autores Associados, 2003.

VENÂNCIO, João. "A educação de jovens e adultos na primeira etapa do ensino fundamental no município do Marília/SP" In: Revista Científica Eletrônica de Pedagogia, da Faculdade de Ciências Humanas de Garça, ano V, n. 10, jul, 2007.

VIEIRA, Evaldo. Estado e miséria social no Brasil: de Getúlio a Geisel. São Paulo: Cortez, 1987. 